\title{
RETROPERITONEAL MASS: TALK NERVES TO ME (Retroperitoneal femoral schwannoma with postoperative iatrogenic femoral neuropathy: case report)
}

\author{
VEDRANA BIOŠIĆ ${ }^{1}$, PETAR MATOŠEVIĆ ${ }^{2}$, GORAN AUGUSTIN ${ }^{2}$ and EMIL KINDA ${ }^{2}$ \\ ${ }^{1}$ Department of Abdominal and Pediatric Surgery, County Hospital Čakovec, Čakovec, Croatia; \\ ${ }^{2}$ Department of Surgery, University Hospital Centre Zagreb, Zagreb, Croatia
}

\section{Summary}

Retroperitoneal femoral schwannomas constitute a rather small percentage of primary retroperitoneal tumors. Proper preoperative diagnosis is often difficult since imaging studies are nonspecific and differential diagnosis quite extensive. We present the case of a 71-year-old patient with a radiologically described retroperitoneal mass - postoperatively confirmed by pathohistology as a benign schwannoma. The tumor was removed in toto; however, the postoperative course was complicated with symptoms of femoral nerve damage. Although benign in nature (and exceedingly rare to turn malignant) schwannomas are treated surgically as the rate of complete resection without nerve damage is high. Left untreated they gain in mass and can cause significant pain due to displacement of the involved nerve.

The significance of this case report is in highlighting the importance of considering schwannomas as a differential diagnosis of retroperitoneal tumors which in turn will lead to a strong strategy for avoiding postoperative complications.

KEYWORDS: schwannoma, iatrogenic femoral neuropathy, retroperitoneal mass

\section{INTRODUCTION}

Schwannomas (also called neurilemmomas and neurinomas) are benign mesenchymal proliferations arising from Schwann cells of the peripheral nerve sheath(1-7). They are the most common of benign nerve sheath tumors and malignant transformation is exceedingly rare $(2,4,8,9)$. Often asymptomatic - if pain does occur it is usually caused by growth of the mass which in turn displaces the involved nerve and by means of stretch or compression causes shooting pains along the sensory distribution area of the nerve $(1,4)$. Most commonly associated with vestibular locations or flexor aspects of the extremities (occurring spo-

Corresponding author: Vedrana Biošić, Department of Abdominal and Pediatric Surgery, County Hospital Čakovec, I.G. Kovačića 1e, 40000 Čakovec, Croatia. e-mail: vedrana.biosic@gmail.com radically or like multiple lesions within neurofibromatosis syndromes or schwanomatosis)(1), a retroperitoneal schwannoma such as we describe in this case report is rare.

Our patient was an example of a retroperitoneal femoral schwannoma found incidentally during a routine urological examination. The treatment was surgical (extirpation/enucleation of the tumor in toto) with a postoperative complication of femoral neuropathy due to iatrogenic femoral nerve injury.

\section{CASE REPORT}

A 71-year-old male patient was referred to a surgical consult due to an intraabdominal tumefaction visualised by ultrasound during a routine urological check-up. He complained of occasional lower abdominal and medial thigh pain that 


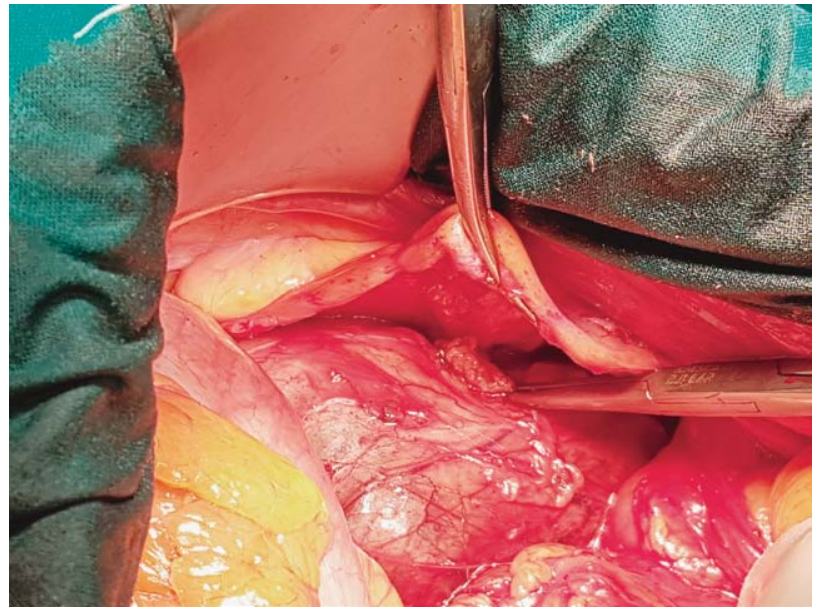

Figure 1 Intraoperative view

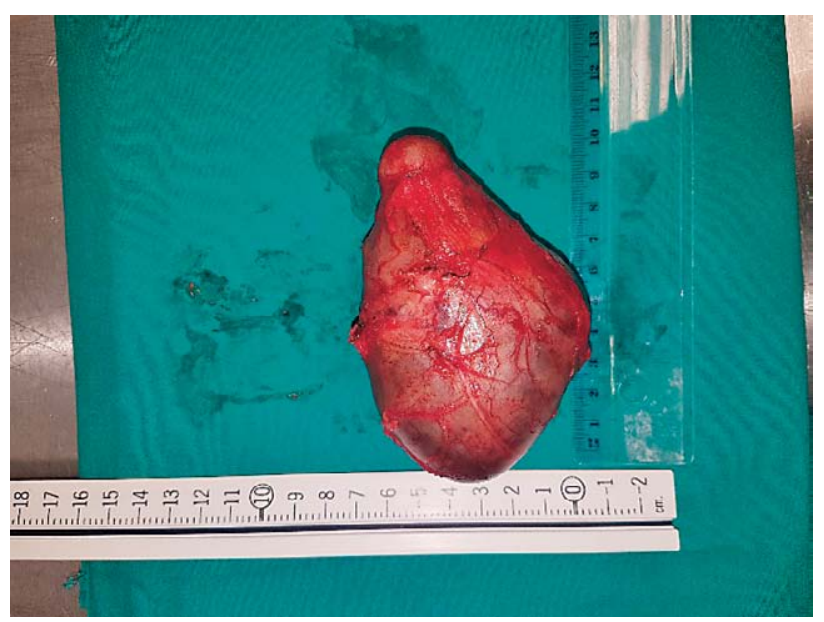

Figure 2 The extracted tumor specimen

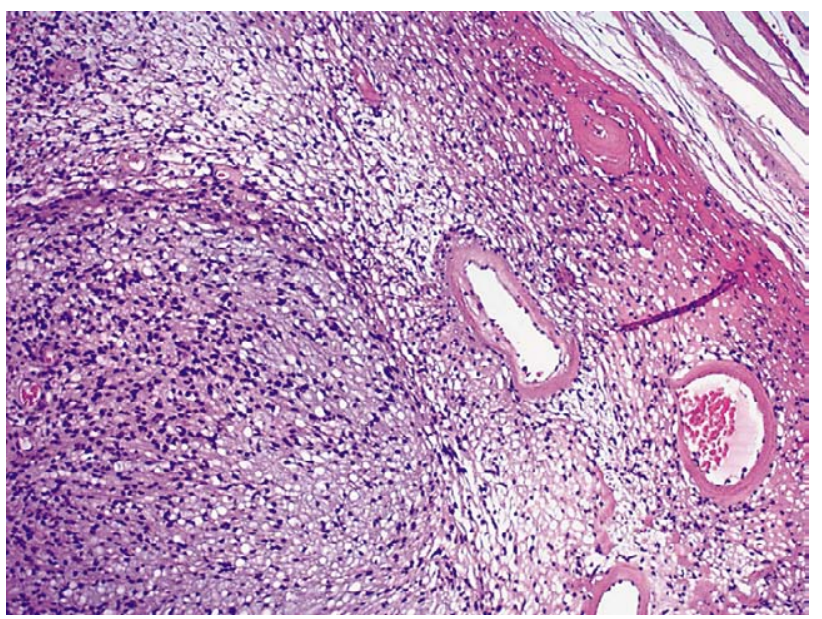

Figure 3 Microscopic view: biphasic (Antoni A and Antoni B) pattern of the tumor

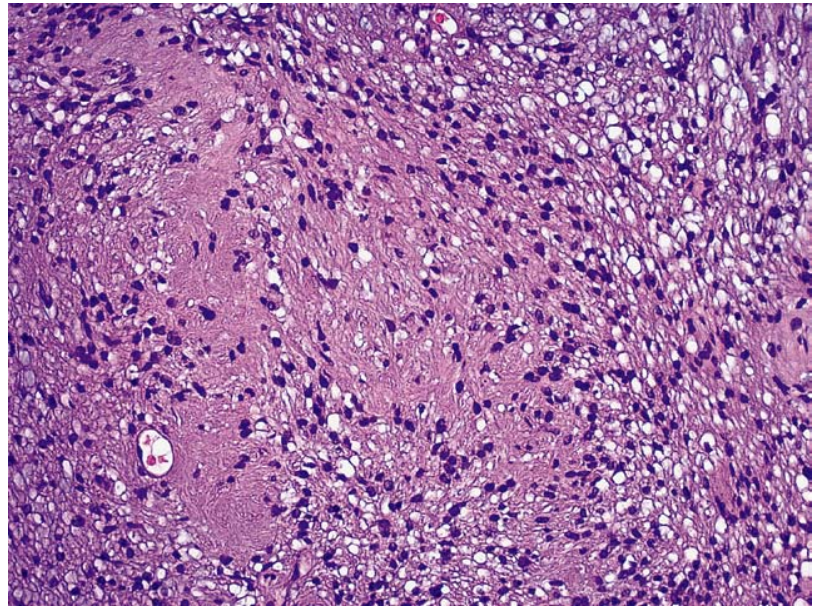

Figure 4 Microscopic view: nuclear palisading, the so-called Verocay bodies (HEE, 200x)

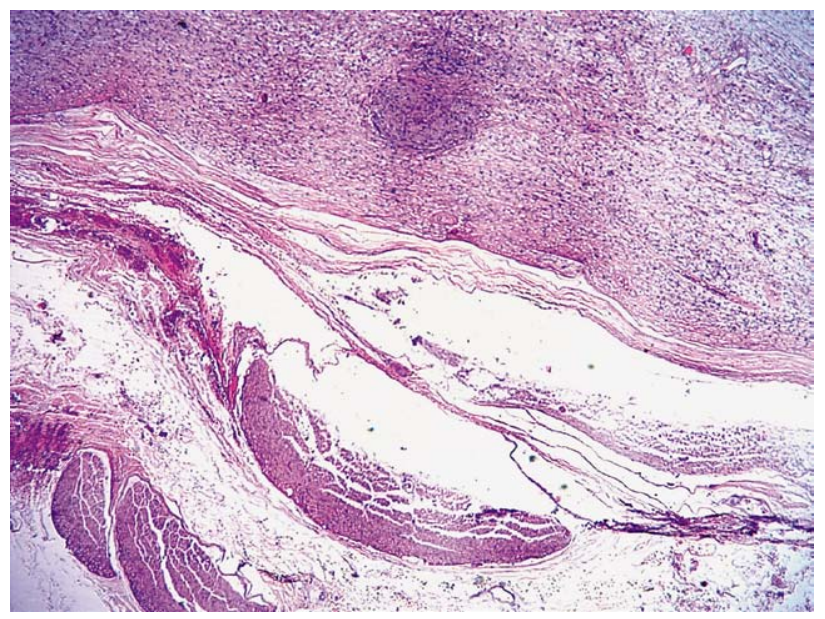

Figure 5 Microscopic view: peripheral nerve adjacent to the tumour capsule (HEE, 25x)".

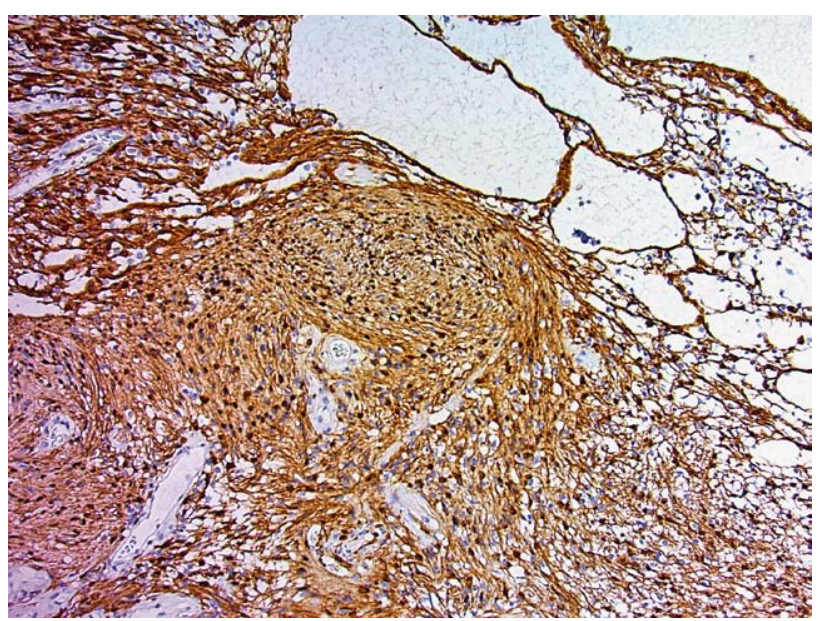

Figure 6 Positive immunohistochemical reaction for S-100 protein $(100 x)$ 
wasn't harsh, would regress spontaneously and never required emergent treatment. An examination of his medical history showed a childhood appendectomy, cholecystectomy a few years prior and nephrectomy due to hydronephrosis. He also had regular urological follow-ups for benign prostate hyperplasia. During an urological visit a retroperitoneal mass was discovered by ultrasound, later described on computed tomography (CT) as a cyst of the mesentery/retroperitoneum, measuring $10 \mathrm{~cm}$ in diameter, extending to the rectum. Endoscopic gastrointestinal diagnostics did not show any pathology and laboratory findings with tumor markers were unremarkable. An explorative laparotomy was performed. Intraoperatively we found a retroperitoneal mass measuring 10x5 $\mathrm{cm}$, situated behind the left psoas muscle, adjacent to the femoral nerve (Figures 1 and 2). A careful preparation was carried out and the mass was extirpated en bloc. No signs of malignancy and lymphadenopathy were found. On the first postoperative day the patient complained of left leg weakness. He could walk only with the help of a walking frame and complained of knee buckling whilst standing. Hip flexion and knee extension were not possible actively. A sensory deficit of the medial aspect of the left thigh was also established. A neurological consult was seeked out with the neurospecialist ordering a magnetic resonance (MR) of the pelvis and lumbosacral spine. The latter showed postoperative changes in the psoas muscle without any residual tumor mass. The MR also showed femoral nerve edema along its course from the L3/L4 roots to the inguinal ligament. The diagnosis of iatrogenic femoral neuropathy was established. The patient was referred to physical therapy and a 4-week postoperative electromyoneurography (EMNG) was scheduled. The pathohistological diagnosis of the tumor specimen was that of a schwannoma with Antoni A and $B$ patterns and nuclear palisading (Figures 3 - 6). The tumor was extirpated in its entirety. After extensive physical therapy 4 weeks postoperatively the EMNG showed severe (but still partial) femoral nerve damage without signs of reinervation. The follow up nerve-conduct studies leading up to the 6-months-postoperative mark (after numerous physical and biofeedback therapy rounds) were only slightly improved although some of the sensory deficit was diminished and the patient walk has somewhat ameliorated as he was now using a single crutch. A year after the surgery the patient is still undergoing ambulatory physical therapy. Knee extension deficit remained, and quadriceps hypotrophy was still evident.

\section{DISCUSSION}

As far as diagnosing medical problems, some would say nowadays we have it easy. With the vast array of radiological examinations, it has perhaps become exceedingly rare that surgical professionals find themselves surprised by the intraoperative discovery. This is of course beneficial for establishing an optimal treatment plan. But the human body does not always play by the pathology book's most frequent rules and it sometimes likes to dabble in the rare section. A lesion cannot always be completely defined by radiological imaging, and clinical findings are not consistently straightforward. Retroperitoneal schwannomas represent only $3 \%$ of all schwannoma cases, and out of all primary retroperitoneal tumors only $4 \%$ are schwannomas $(1,2,5,8,10,11)$. On account of the space available, retroperitoneal schwannomas can grow unrestricted and get quite extensive in size before giving of any symptoms $(6,11)$. Often detected incidentally, any manifestation of the retroperitoneal schwannoma can be contributed to adjacent nerve or organ displacement and case reports describe complaints such as dysuria or hydronephrosis with ureter or bladder compression, gynaecological symptoms, leg oedema caused by partial obstruction of the iliac blood vessels, abdominal distension and paraesthesia along the course of the nerve involved $(1,2,5,7,8,12)$. Schwannomas do not have a distinct radiologic appearance - one study points out the spindle or ovoid shape schwannomas have on CT(13), another study mentions the importance of a radiologist familiar with the more pathognomonic radiological aspects of other retroperitoneal lesions, so schwannoma can partially be a diagnosis of exclusion(4). In any case, the final diagnosis has to be histological and immunohistochemical $(1,14)$. On CT schwannomas often appear as hypodense lesions (our tumor was described as a cystic mass) and certain forms, the so-called cellular schwannomas, can occasionally even be mistaken for malignancies since they are prone to eroding bone and when large in size appear inhomogeneous 
with cystic degeneration and calcifications $(1,5,8$, 12,15). Malignant transformation is extremely rare though, and is most often associated with von Recklinghausen disease $(1,2,9)$ (neurofibromatosis type 1). Histologically, schwannomas are characterised by alternating patterns of hypercellular Antoni A and looser Antoni B patterns. Nuclear palisading is a typical feature(3). S100 protein positivity is characteristically found by immunohistochemical methods(6,16).(Figure 6) Schwannomas are eccentric nerve sheath tumors and well encapsulated; therefore, it is often possible to remove them in their entirety(17). While considering the retroperitoneal location, one has to bear in mind a few unfortunate intraoperative circumstances: large masses in the retroperitoneum are often closely involved with blood vessels of the area and damage to the latter is a very real peril. In addition, schwannomas often have an elaborate pathological vascularisation and huge haemorrhages from sacral, lumbar and internal iliac vessels are possible $(1,8)$. In his study of 82 patients with retroperitoneal schwannomas, $\mathrm{Li}$ showed that in $11 \%$ of all cases a complete tumor removal was not possible due to close association with large blood vessels including the vena cava and aorta, so only a biopsy was taken. He also strongly advocated vascular isolation as to avoid before mentioned complications(9). As for iatrogenic femoral nerve damage it is most often described after orthopedic surgeries such as hip replacements and pelvic gynecological operations. Tumor resections are thought to be the cause of femoral nerve damage in 15,4\% cases(18). Treatment is conservative when possible but if motor deficit and pain persist, surgery is undertaken where neurolysis is performed(18).

\section{CONCLUSION}

In the already mentioned study that Li wrote with his colleagues, he found that in only $15,9 \%$ of retroperitoneal schwannoma cases a correct preoperative diagnosis was achieved(9). Another study found that most treatment oversights were owed to this diagnosis not even being considered preoperatively(4). Retroperitoneal schwannomas are not unheard of, but they are unusual. Case reports such as this one help us gain knowledge and consider a more wide-ranging spectrum of differ- ential diagnoses when confronted with our patient thus making better decisions with better (hopefully optimal) outcomes. After all, a good strategy is a battle half won.

\section{REFFERENCES}

1. Theodosopoulos T, Stafyla VK, Tsiantoula P, et al. Special problems encountering surgical management of large retroperitoneal schwannomas. World Journal of Surgical Oncology. 2008;6. doi:10.1186/1477-7819-6-107

2. Gubbay AD, Moschilla G, Gray BN, Thompson I. Retroperitoneal schwanomma: a cese series and review. 1995. Aust N Z J Surg. 1995 Mar;65(3):197-200.doi: 10.1111/j.1445-2197.1995.tb00607.x.

3. Guz BV, Wood D, Montie JE, Pontes JE. Retroperitoneal neural sheath tumors: Cleveland Clinic experience. The Journal of Urology, 1989 Dec;142(6):1434-7. doi: 10.1016/s0022-5347(17)39119-x.

4. Knight DMA, Birch R, Pringle J. Benign solitary schwannomas A REVIEW OF 234 CASES. J Bone Joint Surg Br. 2007 Mar;89(3):3827. doi:10.1302/0301620X.89B3

5. Chiang ER, Chang MC, Chen TH. Giant retroperitoneal schwannoma from the fifth lumbar nerve root with vertebral body osteolysis: A case report and literature review. Archives of Orthopaedic and Trauma Surgery. 2009;129(4):495-499. doi:10.1007/s00402-0080635-5

6. Daneshmand S, Youssefzadeh D, Chamie K, et al. Benign retroperitoneal schwannoma: A case series and review of the literature. Urology. 2003;62(6):993-997. doi:10.1016/S0090-4295(03)00792-1

7. Kim DH, Murovic JA, Tiel RL, Moes G, Kline DG. A Series of 397 Peripheral Neural Sheath Tumors:30Year Experience at Louisiana State University Health Sciences Center. J Neurosurg. 2005 Feb;102(2):246-55. doi: 10.3171/jns.2005.102.2.0246.

8. Patocskai EJ, Tabatabaian M, Thomas MJ. Cellular schwannoma: a rare presacral tumour. Canadian Journal of Surgery. 2002;45(2):141-4.

9. Li Q, Gao C, Juzi JT, Hao X. Analysis of 82 cases of retroperitoneal schwannoma. ANZ Journal of Surgery. 2007;77(4):237-240. doi:10.1111/j.1445-2197.2007. 04025.X

10. Xu SY, Sun K, Xie HY, Zhou L, Zheng S sen, Wang WL. Hemorrhagic, calcified, and ossified benign retroperitoneal schwannoma: First case report. Medicine (United States). 2016;95(30). doi:10.1097/MD.00000000000 04318

11. Çaliskan S, Gümrükçü G, Kaya C. Retroperitoneal Ancient Schwannoma: A Case Report. Rev Urol. 2015; 17(3): 190-193.doi:10.3909/riu0638

12. Dede M, Yagci G, Yenen MC, Gorgulu S. Retroperitoneal Benign Schwannoma: Report of Three Cases ans Analysis of Clinico-Radiologic Findings. Tohoku J ExpMed. 2003;200:93-97. 
13. Li CS, Huang GS, Wu H da, et al. Differentiation of soft tissue benign and malignant peripheral nerve sheath tumors with magnetic resonance imaging. Clinical Imaging. 2008;32(2):121-127. doi:10.1016/j. clinimag.2007.05.006

14. Leal-Filho MB, da Silva Júnior RG, Pinheiro-Leal LM, Montechi LN, Lima IWS. Femoral nerve schwannoma. Jornal Brasileiro De Neurocirurgia. 2018;23(2):166-168. doi:10.22290/jbnc.v23i2.1169

15. Ratnagiri $R$, Mallikarjun S. Retroperitoneal ancient schwannoma: Two cases and review of literature. Journal of Cancer Research and Therapeutics. 2014;10(2):368-370. doi:10.4103/0973-1482.136660
16. Stefansson K, Wollmann R, Jerkovic M. S-100 Protein in Soft-Tissue Tumors Derived From Schwann Cells and Melanocytes. Am J Pathol. 1982 Feb;106(2):261-8.

17. Peace WJ, Pacelli LL, Botte MJ. Schwannoma of the Femoral Nerve. Current Orthopaedic Practice 2009; 20(6):695-697. Doi: 10.1097/BCO.0b013e3181be034b

18. Piza-Katzer H, Schöller T, Stichelberger M. Iatrogene N. femoralis-läsionen. Handchirurgie Mikrochirurgie Plastische Chirurgie. 2009;41(4):230-237. doi: 10.1055/ s-2008-1039296

\section{Sažetak}

TUMOR RETROPERITONEUMA: PRIČAJ MI O ŽIVCIMA

Retroperitonealni femoralni schwannom sa jatrogenom postoperacijskom femoralnom neuropatijom: prikaz slučaja

\section{Biošić, P. Matošević, G. Augustin, E. Kinda}

Retroperitonealni schwannomi femoralnog živca predstavljaju mali udio primarnih tumora retroperitoneuma. Uzimajući u obzir kako je radiološka dijagnostika u ovom slučaju nespecifična, a diferencijalna dijagnoza primarnih retroperitonealnih tumora široka, ispravnu preoperacijsku dijagnozu ponekad je teško postići. U ovom radu prikazat ćemo slučaj 71-godišnjeg pacijenta sa radiološki opisanim tumorom retroperitoneuma koji je nakon kirurške ekstirpacije patohistološki definiran kao schwannom. Tumor je odstranjen u cijelosti, međutim postoperacijski tijek kompliciran je simptomima jatrogenog oštećenja femoralnog živca. Iako su schwannomi uglavnom dobroćudni tumori uz rijetke slučajeve maligne alteracije, njihovo liječenje prvenstveno je kirurško. Postotak cjelovite resekcije bez oštećenja živca je visok. Neliječeni schwanomi dobivaju na masi te uzrokuju bol pomicanjem i pritiskanjem okolnih struktura.

Važnost ovog prikaza leži u naglašavanju femoralnog schwannoma kao diferencijalno-dijagnostičke mogućnosti u razmatranju retroperitonealnih tumora. Na taj način može se stvoriti uspješna strategija sprječavanja postoperacijskih komplikacija.

KLJUČNE RIJEČI: schwannom, jatrogena neuropatija femoralnog živca, tumor retroperitoneuma 